Florida A\&M University College of Law

Scholarly Commons @ FAMU Law

2014

"What He Said." The Transformative Potential of the Use of Copyrighted Content in Political Campaigns -or- How a Win for Mitt Romney Might Have Been a Victory for Free Speech

Deidre Keller

Follow this and additional works at: https://commons.law.famu.edu/faculty-research

Part of the Constitutional Law Commons, First Amendment Commons, and the Intellectual Property Law Commons 


\title{
"What He Said." The Transformative Potential of the Use of Copyrighted Content in Political Campaigns -or- \\ How a Win for Mitt Romney Might Have Been a Victory for Free Speech
}

\author{
Deidré A. Keller*
}

\begin{abstract}
In January 2012 Mitt Romney's campaign received a cease-and-desist letter charging, among other things, that its use of news footage concerning Newt Gingrich's ethics problems in the House of Representatives constituted a violation of NBC's copyright. This is just the latest such charge and came amidst similar allegations against the Gingrich and Bachmann campaigns and in the wake of similar allegations against both the McCain and Obama campaigns in 2008. Such allegations have plagued political campaigns as far back as Reagan's in 1984. The existing literature is nearly devoid of a consideration of such uses as political speech protected by the First Amendment. Rather, scholars tend to focus on fair use. Courts have considered this question very rarely and also tend to concentrate on fair use. Because these cases rarely progress to decisions, there is little to be said of what courts have done but much to be said of what they ought

Associate Professor of Law, Claude W. Pettit College of Law, Ohio Northern University. Thanks are due to the participants at the Central States Law Schools Association Conference (2012) where an early version of this paper was presented, the participants at the Regional Faculty Workshop held in February 2013 at Valparaiso University Law School especially Curt W. Cichowski and Michael D. Murray whose lively discussion of the paper provided me with invaluable insights and a title, and the faculty at the University of Kentucky where I presented a version of the paper and received helpful feedback. I am thankful to Brian Frye for the invitation to present the paper there. I must also thank my colleagues at ONU whose support is unwavering, especially Joanne Brant whose brain I picked mercilessly for suggestions on the First Amendment aspects of the paper. For research assistance, I am thankful to Kelli Vaughn, Christopher Mosley, and Laura Waymire. All errors and omissions are mine alone.
\end{abstract}


to. This Article engages in a thought experiment of laying out the legal analysis in the case that will never be-NBC $v$. Romney-arguing that when copyrighted content is marshaled to advance a political message, copyright ought to yield to the First Amendment.

\section{TABLE OF CONTENTS}

I. INTRODUCTION

II. THE COPYRIGHT ACT-FIRST AMENDMENT INTERFACE: CAN THE First AMENDMENT BE CREDIBLy ASSERTED IN A COPYRIGHT INFRINGEMENT CASE?.

III. CONSIDERING NBC $V$. ROMNEY FROM THE PERSPECTIVE OF THE FIRST AMENDMENT. 508

A. The Copyright Act, as Applied to the Use of Content in the Context of Political Campaigns, is Arguably Unconstitutionally Vague.... 509

B. Campaign Speech Has Long Enjoyed Special Protection Under the First Amendment 510

C. Allowing Any Remedy in these Circumstances Would Infringe the Constitutionally Protected Freedom to Listen...

D. Anticipating the First Amendment Offense: The Right Not to Speak, Compelled Speech, and Expressive Association ...

IV. THE COPYRIGHT APPROACH TO NBC V. ROMNEY: Do THE INTERNAL SAFEgUARDS PROTECT THE FIRST AMENDMENT INTERESTS?

A. Idea-Expression Dichotomy: Considering the Copyrightability of News and Infringement by Reproduction

B. The Infringement Analysis ...................................... 520

C. Fair Use .............................................................. 521

1. The Purpose and Character of the Use............. 522

2. The Nature of the Copyrighted Work ............... 526

3. The Amount and Substantiality Taken ............ 527

4. The Effect on the Market for the Work ............. 528

5. Fair Use: Conclusion .................................. 528

V. AN ATTEMPT AT HARMONIZATION: REALIZING THE FIRST AMENDMENT Potential of TRANSFORMATIVENESS ......... 529

VI. CONCLUSION ................................................... 530 
"Men speak of freedom of belief and freedom of property as if, in the Constitution, the word 'freedom,' as used in these two cases, had the same meaning. Because of that confusion, we are in constant danger of giving to a man's possessions the same dignity, the same status, as we give to the man himself." 1

"First Amendment protections [are] embodied in the Copyright Act's distinction between copyrightable expression and uncopyrightable facts and ideas, and the latitude for scholarship and comment traditionally afforded by fair use ....”2

\section{INTRODUCTION}

Consider the following scenario: In connection with a campaign for office, a politician airs an advertisement that uses a song. Someone objects by way of a cease-and-desist letter, threatening to sue the campaign. The campaign removes the advertisement from the airwaves or ceases using the song.

Initially, this may seem like an unlikely scenario. After all, the First Amendment implications of political speech and discussions of political issues seem obvious. ${ }^{3}$ Nonetheless, similar scenarios have played out in many political campaigns at all levels of government. ${ }^{4}$ One candidate for office even used the copyright in her website posts to compel an opposing candidate to stop using her own words against her. ${ }^{5}$ When First Amendment and copyright issues collide in the

1. Alexander Meiklejohn, Political Freedom: The Constitutional Powers of THE PEOPLE 9 (1948).

2. $\quad$ Harper \& Row, Publishers, Inc. v. Nation Enters., 471 U.S. 539, 560 (1985).

3. See, e.g., Buckley v. Valeo, 424 U.S. 1, 14 (1976).

4. See, e.g., Jack Doyle, I'm a Dole Man, 1996, The Pop History Dig (Dec. 3, 2009), http://www.pophistorydig.com/?p=4891 (describing Bob Dole's use of a version of "Soul Man" in his 1996 presidential election campaign and the ensuing allegations of infringement); Jack Doyle, I Won't Back Down, 1989-2008, The PoP History Dig (Mar. 7, 2009), http://www.pophistorydig.com/?p=932 (describing George W. Bush's use of Tom Petty's "I Won't Back Down" and Petty's objections to same); Gary Graff, David Byrne Sues Florida Gov. Charlie Crist for $\$ 1$ Million, BILlBOARD (May 24, 2010, 2:31 PM), http://www.billboard.com/news/davidbyrne-sues-florida-gov-charlie-crist-1004093436.story\#/news/david-byrne-sues-florida-govcharlie-crist-1004093436.story (describing copyright infringement lawsuit against Charlie Crist for using the song "Road to Nowhere" in an ad during his campaign for Senate); Martin Lewis, Chris Christie Rips off Monty Python, Troupe Threatens Suit, HufF Post New YoRK: The BloG (Nov. 1, 2009, 6:17 PM), http://www.huffingtonpost.com/martin-lewis/chris-christie-rips-offm_b_341598.html (describing accusations of copyright infringement against Chris Christie for use of a Monty Python sketch in an ad during his campaign for Governor of New Jersey in 2010).

5. $\quad$ See Eric Kleefeld, Angle Sends Cease-and-Desist to Reid -- For Reposting Her Own Website, TALKING PoINTS MeMo (July 5, 2010, 2:52 PM), http://talkingpointsmemo.com/dc/anglesends-cease-and-desist-to-reid-for-reposting-her-own-website. 
context of campaign politics, high stakes and short timelines make even untenable challenges possible.

During the Republican primary campaign leading up to the 2012 presidential election, copyright owners objected to the use of content in at least seven different instances. ${ }^{6}$ The majority of these objections concerned the use of sound recordings at campaign events. ${ }^{7}$ But one-the scenario that will be the focus of this Article-concerned the use of a news report in a campaign ad. ${ }^{8}$ This Article focuses on the use of news footage rather than songs because an ASCAP or BMI license usually covers the songs used on the campaign trail. ${ }^{9}$ Therefore, protestations to the contrary notwithstanding, such uses seldom implicate viable copyright infringement claims. Rather, artists rely on the Lanham Act and the right of publicity to assert that use of their songs at campaign events falsely implies some relationship between the artist and the politician or the political message. ${ }^{10}$ Therefore, in order to address the copyright issues, this Article focuses on a situation in which copyright was front and center-the dispute between Mitt Romney and the National Broadcasting Company (NBC) concerning the use of certain news footage. ${ }^{11}$

6. See Katie Byrne, K'Naan Wants Mitt Romney to Stop Using Waving Flag, MTV (Feb. 1, 2012, 7:50 PM), http://www.mtv.com/news/articles/1678368/knaan-mitt-romney-wavingflag.jhtml ("Waving Flag"); Miriam Coleman, Newt Gingrich Ordered to Stop Using 'How You Like Me Now?', ROLLING STONE (Jan. 28, 2012, 1:30 PM), http://www.rollingstone.com/music/news/newt-gingrich-ordered-to-stop-using-how-you-like-menow-20120128 ("How You Like Me Now?"); Andy Greene, Katrina and the Waves Join Tom Petty's Fight Against Michele Bachmann, Rolling STONE (June 29, 2011, 3:50 PM), http://www.rollingstone.com/politics/news/katrina-and-the-waves-join-tom-pettys-fight-againstmichele-bachmann-20110629 ("Walking on Sunshine"); Alleged Copyright Infringement and Newt Gingrich: What's All the Fuss?, Dickinson LaW: IOWA InTELLECTUAL PROPERTY Blog (Feb. 1, 2012), http://www.dickinsonlaw.com/2012/02/allegedcopyright-infringement-and-newtgingrich-whats-all-the-fuss ("Eye of the Tiger"); Silversun Pickups Tell Romney to Stop Using 'Panic Switch', Rolling STONE Music (Aug. 16, 2012, 9:50 AM), http://www.rollingstone.com/music/news/silversun-pickups-tells-romney-to-stop-using-panicswitch-20120816 ("Panic Switch"); Tom Petty to Michele Bachmann: Stop Playing 'American Girl', HufFington POST (June 28, 2011, 7:15 PM), http://www.huffingtonpost.com/ 2011/06/28/tom-petty-michele-bachmann_n_886384.html (“American Girl”).

7. See sources cited supra note 6.

8. See Tierney Sneed, Should Mitt Romney Withdraw His Tom Brokaw Ad?, U.S. NEWs (Jan. 30, 2012), http://www.usnews.com/opinion/articles/2012/01/30/should-mitt-romneywithdraw-his-tom-brokaw-ad.

9. See Meredith Filak, Campaigns, Copyrights, and Compositions: A Politician's Guide to Music on the Campaign Trail, PuBliC Knowledge (July 6, 2011, updated July 7, 2011), http://publicknowledge.org/blog/campaigns-copyrights-and-compositions-politic.

10. See generally Sarah Schacter, Note, The Barracuda Lacuna: Music, Political Campaigns, and the First Amendment, 99 GEO. L.J. 571, 587-97 (2011) (discussing the endorsement aspects of a claim based on the use of music on the campaign trail).

11. See infra notes 18-24 and accompanying text. 
In the middle of the fight of his life, his bid for the 2012 Republican presidential nomination, Mitt Romney ended up entangled in a very different fight-the long-standing battle between copyright and the First Amendment. ${ }^{12}$ Romney was not the only candidate waging this two-front war; both Newt Gingrich and Michele Bachmann also faced claims of copyright infringement. ${ }^{13}$ In fact, while Romney ${ }^{14}$ and Bachmann capitulated to the demands that they cease using certain copyrighted content, ${ }^{15}$ Gingrich was ultimately sued. ${ }^{16}$ Like most suits that arise in this context, the Gingrich matter settled quickly. ${ }^{17}$ The dispute between Romney and NBC provides an interesting point of departure for a thought experiment about what might happen if a court actually decided such a copyright infringement suit on its merits.

On Friday, January 27, 2012, four days before the Republican primary in Florida, the Romney campaign began running an ad there entitled "History Lesson."18 The thirty-second ad consisted solely of a snippet of an NBC Nightly News report that originally aired on January 21, 1997.19 The snippet in the ad showed Tom Brokaw reporting on the end of Newt Gingrich's career in the US House of Representatives. Brokaw said:

Good evening. Newt Gingrich, who came to power, after all, preaching a higher standard in American politics; a man who brought down another Speaker on ethics accusations - tonight he has on his own record the judgment of his peers, Democrat and Republican alike. By an overwhelming vote, they found him guilty of ethics violations; they charged him a very large financial penalty; and they raised, several of them, raised serious questions about his future effectiveness. ${ }^{20}$

12. See generally Joseph P. Bauer, Copyright and the First Amendment: Comrades, Combatants, or Uneasy Allies?, 67 WASH. \& LEE L. REV. 831 (2010) (describing the conflict between the copyright regime and First Amendment principles).

13. See sources cited supra note 6.

14. See James C. McKinley, Jr., G.O.P. Candidates Are Told, Don't Use the Verses, It's Not Your Song, N.Y. TIMES, Feb. 3, 2012, http://www.nytimes.com/2012/02/04/arts/music/romneyand-gingrich-pull-songs-after-complaints.html?pagewanted=all\&_r=0.

15. See id.

16. See Complaint, Rude Music, Inc. v. Newt 2012 Inc., No. 1:12-cv-00640 (N.D. Ill. Jan. 23, 2012).

17. See Joy Lin, Gingrich Settling 'Eye of the Tiger' Lawsuit, FoxNews.Com Politics BLOG (Aug. 24, 2012), http://politics.blogs.foxnews.com/2012/08/24/gingrich-settling-eye-tigerlawsuit.

18. See Daily Mail Reporter, NBC Asks Romney to Stop Running Tom Brokaw Ad Which Undermines Networks 'Journalistic Credibility', MAIL OnLINE (Jan. 28, 2012 11:34 PM), http://www.dailymail.co.uk/news/article-2093324/NBC-asks-Romney-stop-running-Tom-Brokawad-undermines-networks-journalistic-credibility.html [hereinafter NBC Asks Romney] (including embedded video of the ad).

19. See id.

20. $I d$. (transcription of video ad). 
On Saturday, January 28, NBC voiced its objection to the advertisement in a cease-and-desist letter claiming, among other things, copyright infringement. ${ }^{21}$ Later that day, the campaign claimed that its use of the content constituted fair use. ${ }^{22}$ Romney himself responded to NBC's claims on Monday, January 30, saying that the campaign intended to discuss the matter with NBC's lawyers. $^{23}$ Ultimately, the campaign withdrew the ad and removed it from the campaign website. ${ }^{24}$

Such capitulation is the rule rather than the exception. ${ }^{25}$ As a result, there is very little relevant case law considering the merits of such cases. ${ }^{26}$ In lieu thereof, this Article considers how such a case might be-and how it ought to be-resolved judicially.

All of the commentary occurring at the time "History Lesson" aired concerned whether the Romney campaign's use of the footage constituted fair use under the Copyright Act. ${ }^{27}$ At first blush, this may seem odd. After all, the First Amendment affords speech within the context of a political campaign the highest degree of protection. ${ }^{28}$ However, given the United States Supreme Court's prior treatment of First Amendment assertions in the context of copyright suits, ${ }^{29}$ relying upon the fair use doctrine makes sense. ${ }^{30}$ This Article asks whether courts should reconsider the need for First Amendment scrutiny in

21. See id.; see also Dylan Byers, NBC's Letter to the Romney Campaign, PoLiTico (Jan. 28, 2012, 4:02 PM), http://www.politico.com/blogs/media/2012/01/nbcs-letter-to-the-romneycampaign-112662.html (reproducing the letter).

22. See NBC Asks Romney, supra note 18.

23. See Michael Inbar, Romney: We'll Meet With NBC About Brokaw Clip in Ad, TODAY NEWS (Jan. 30, 2012, 9:26 AM), http://www.today.com/id/46188734/ns/todaytoday_news/t/romney-well-meet-nbc-about-brokaw-clip-ad/\#.UT1q5tY3zdd.

24. See Margaret Hartmann, Journalists Unhappy About Unauthorized Romney Ad Cameo, N.Y. MAG., http://nymag.com/daily/intelligencer/2012/07/journalists-unhappy-aboutromney-ad-cameo.html (July 15, 2012, 11:37 PM).

25. See Eriq Gardner, Michele Bahmann in Legal Spat for Using Tom Petty's 'American Girl' at Rally, The Hollywood RePoRTER: Hollywood, Esq. (June 28, 2011, 11:48 AM), http://www.hollywoodreporter.com/thr-esq/michele-bachmann-legal-spat-using-206257 (listing copyright disputes in the context of political campaigns and noting instances of capitulation).

26. In fact, only six decisions considering allegations of copyright infringement in the context of a political campaign can be found. See infra Part IV.

27. See, e.g., Ken Paulson, Copyright Law Favors Romney in Ad's Use of NBC News Report, FIRST AMENDMENT CTR. (Jan. 30, 2012), http://www.firstamendmentcenter.org/copyrightlaw-favors-romney-in-ads-use-of-nbc-news-report; see also Ted Johnson, Fair Use? NBC Asks Romney Campaign to Stop Using Footage in Ad, VARIETY (Jan. 28, 2012, 2:28 PM), http://variety.com/2012/biz/opinion/fair-use-nbc-news-asks-romney-campaign-to-stop-usingfootage-in-ad-36896.

28. See infra Part III.B.

29. See infra notes 49-61 and accompanying text.

30. See infra notes $49-61$ and accompanying text. 
copyright infringement suits, ${ }^{31}$ at least in the limited context where the alleged infringement takes place in the context of a political campaign. In other words, can authors of copyrighted content grant or refuse licenses to political campaigns based solely upon their own ideological perspectives? If we believe that political discourse would suffer if Fox News's content is only available for Republicans and MSNBC's content is only available to Democrats, then the application of First Amendment principles in this context must become more robust.

The Article proceeds to imagine a judicial resolution to the dispute between Mitt Romney and NBC. The intent of this exercise is to provide an example illustrating the tension between copyright and the First Amendment. Most courts have either ducked this tension or held in favor of copyright interests. ${ }^{32}$ This Article demonstrates the need for a more vigorous consideration of First Amendment principles in these circumstances. Part II reviews the jurisprudence addressing First Amendment claims in the copyright context. Part III considers how the conflict between NBC and the Romney campaign might have been resolved if approached from the perspective of the First Amendment. Part IV presents an imagined resolution of the conflict if approached from the perspective of copyright infringement and considers whether the First Amendment interests at issue in such a dispute are truly protected by the fair use defense and idea-expression dichotomy. Ultimately, the Article concludes that-at least where the alleged infringement occurs in the context of a political campaign-the safeguards internal to the Copyright Act, as currently deployed, do not fully protect the First Amendment interests at stake. Part V endeavors to reconcile the Copyright Act with the First Amendment in this context.

\section{The COPYRIGHT ACT-First AMENDMENT INTERFACE: CAN THE First AMENDMENT BE CREDIBly Asserted IN A COPYRIGHT INFRINGEMENT CASE?}

"Concerning the First Amendment . . . some restriction on expression is the inherent and intended effect of every grant of copyright."33 Scores of scholars have considered the potential conflict

\footnotetext{
31. For another recent treatment of this topic, see Patrick Cronin, The Historical Origins of the Conflict Between Copyright and the First Amendment, 35 COLUM. J.L. \& ARTS 221

32. See infra notes 68-70 and accompanying text.

33. Golan v. Holder, 132 S. Ct. 873, 889 (2012).
} (2012). 
between the Copyright Act and the First Amendment. ${ }^{34}$ This scholarly interest began in 1970 with seminal articles by Melville Nimmer ${ }^{35}$ and Paul Goldstein. ${ }^{36}$ Nimmer argued that what he referred to as the "definitional balance" achieved by the idea-expression dichotomy largely mitigated the apparent conflict. ${ }^{37}$ Goldstein, tracing American copyright to its censorial roots, ${ }^{38}$ perceived a broader conflict and asserted the need for accommodation principles taking into account the public interest ${ }^{39}$ - a tack specifically rejected by Nimmer. ${ }^{40}$ While Nimmer recognized some limited instances in which the idea-expression dichotomy did not mitigate the conflict between the First Amendment and the Copyright Act, ${ }^{41}$ the accommodations he suggested were significantly more limited than those suggested by Goldstein. ${ }^{42}$ This is hardly surprising given Goldstein and Nimmer's differing perceptions as to the breadth of the conflict.

Courts that have considered conflicts between the First Amendment and the Copyright Act have generally held that both the idea-expression dichotomy and fair use operate to check any perceived conflict. ${ }^{43}$ However, the vast majority of scholars, building on Nimmer and Goldstein's foundations, have argued that these internal

34. See generally DAVID L. LANGe \& H. JEFFERSon POWELl, No LAW: INTELlectual Property in the Image of an Absolute First Amendment (2009); NeIl Weinstock Netanel, Copyright's PARAdOX (2008); Yochai Benkler, Free as the Air to Common Use: First Amendment Constraints on Enclosure of the Public Domain, 74 N.Y.U. L. REV. 354 (1999); Lawrence Lessig, Lecture, Copyright's First Amendment, 48 UCLA L. REV. 1057 (2001); Adrian Liu, Copyright as Quasi-Public Property: Reinterpreting the Conflict Between Copyright and the First Amendment, 18 Fordham Intell. Prop. Media \& EnT. L.J. 383 (2008); Neil Weinstock Netanel, Locating Copyright Within the First Amendment Skein, 54 STAN. L. REV. 1 (2001); Rebecca Tushnet, Copy this Essay: How Fair Use Doctrine Harms Free Speech and How Copying Serves It, 114 YALE L.J. 535, 546 (2004); Eugene Volokh, Freedom of Speech and Intellectual Property: Some Thoughts After Eldred, 44 Liquormart, and Bartnicki, 40 Hous. L. REV. 697 (2003).

35. Melville B. Nimmer, Does Copyright Abridge the First Amendment Guarantees of Free Speech and the Press?, 17 UCLA L. REV. 1180 (1970).

36. Paul Goldstein, Copyright and the First Amendment, 70 CoLUM. L. REV. 983 (1970).

37. Nimmer, supra note 35, at 1189-93.

38. Goldstein, supra note 36, at 983.

39. Id. at 988 .

40. Nimmer, supra note 35, at 1199.

41. Id. at 1193-1200. Notably, one such instance perceived by Nimmer as problematic was the use of news photographs. $I d$. at 1199. Nimmer defines news photographs as "all products of the photographic and analogous processes, including motion picture film and video tape ... if the event depicted in the photograph, as distinguished from the fact that the photograph was made, is the subject of news stories appearing in newspapers throughout the country." Id. This would appear to place all photographs and broadcasts of news carriers outside of the purview of copyright. However, cases decided since Nimmer's article make it clear that such is not the case. See infra notes 156-161 and accompanying text.

42. Nimmer, supra note 35 , at 1200.

43. See infra note 145 and accompanying text. 
mechanisms are insufficient to protect the inherent free speech concerns; therefore, the Copyright Act ought to be subject to First Amendment scrutiny. ${ }^{44}$ For example, one scholar recently argued that, where the derivative works right is at issue, the Copyright Act is susceptible to a First Amendment challenge based upon overbreadth and vagueness. ${ }^{45}$ Another has asserted that the First Amendment cannot aid in resolving copyright disputes because there are First Amendment values on both sides in any copyright infringement suit. ${ }^{46}$

This Article seeks to bring some of these theoretical forays down to earth. It reflects upon a situation in which a political campaign used copyrighted content without obtaining the copyright owner's permission. Although such disputes arise every campaign season, because the campaigns (the alleged infringers) tend to concede to the demands of copyright owners, commentators are unlikely to have definitive case law upon which to rely any time soon. ${ }^{47}$ This Article attempts to fill the void left in the absence of such cases and, in so doing, to demonstrate that the current approach to these issues results in chilling important political speech.

In a sense, it is not at all surprising that the Romney campaign ceased running the "History Lesson" ad in the face of NBC's objections. NBC's cease-and-desist letter came a mere ten days after the Supreme Court's decision in Golan v. Holder. ${ }^{48}$ The Golan Court held that the Uruguay Round Agreement Act, ${ }^{49}$ which restored copyright protection to various works of foreign authors, did not require heightened First Amendment scrutiny. ${ }^{50}$ In so holding, the Court merely extended the approach it took in Eldred $v$. Ashcroft in which it considered whether the Copyright Term Extension Act ${ }^{51}$ (CTEA) ran afoul of the First Amendment. ${ }^{52}$ The CTEA extended the term of all existing copyrights by twenty years, ${ }^{53}$ and the Court held that no heightened First Amendment scrutiny was required because

\footnotetext{
44. See, e.g., Jed Rubenfeld, The Freedom of Imagination: Copyright's Constitutionality, 112 YALE L.J. 1 (2002).

45. Christina Bohannan, Taming the Derivative Works Right: A Modest Proposal for Reducing Overbreadth and Vagueness in Copyright, 12 VAND. J. ENT. \& TECH L. 669 (2010).

46. David McGowan, Why the First Amendment Cannot Dictate Copyright Policy, 65 U. PITT. L. REV. 281 (2004).

47. See infra Part IV.

48. Golan v. Holder, 132 S. Ct. 873 (2012).

49. Codified at 17 U.S.C. $§ 104$ A.

50. See Golan, 132 S. Ct. at 878.

51. Sonny Bono Copyright Term Extension Act, Pub. L. No. 105-298, 112 Stat. 2827

52. See Eldred v. Ashcroft, 537 U.S. 186, 218-21 (2003).

53. Sonny Bono Copyright Term Extension Act $§ 102$.
} (1998). 
the law did not affect "the traditional contours of copyright." ${ }_{54}$ The Golan Court later defined the term "traditional contours" of copyright as limited to the idea-expression dichotomy and the affirmative defense of fair use. ${ }^{55}$ In both Golan and Eldred, the Court rejected facial First Amendment challenges to Copyright Act revisions. ${ }^{56}$ One potential area for First Amendment consideration, then, may be an as-applied challenge.

The last time the Court considered an as-applied First Amendment challenge to the Copyright Act was Harper \& Row Publishers, Inc. v. Nation Enterprises. ${ }^{57}$ In Harper \& Row, Nation Enterprises answered Harper \& Row's copyright infringement claim by asserting that its use of President Ford's memoir was privileged under the First Amendment. ${ }^{58}$ Specifically, Nation Enterprises argued that the freedom of press guaranteed by the First Amendment protected its use of the newsworthy content. ${ }^{59}$ Rejecting this argument, the Court stated: "In our haste to disseminate news it should not be forgotten that the Framers intended copyright itself to be the engine of free expression. By establishing a marketable right to the use of one's expression, copyright supplies the economic incentive to create and disseminate ideas." 60

In the wake of Harper \& Row, lower courts have consistently rejected the First Amendment as a defense to a copyright infringement claim. ${ }^{61}$ Although the United States Court of Appeals for the Eleventh Circuit issued a decision finding that that the issuance of an injunction in a copyright infringement suit constituted a prior restraint in violation of the First Amendment, ${ }^{62}$ the court ultimately vacated its decision, replacing it with one focused on the fair use defense. ${ }^{63}$ While there are no decisions directly addressing the issue of whether the use of copyrighted content in the context of a

\footnotetext{
54. $\quad$ Eldred, 537 U.S. at 221.

55. Golan, 132 S. Ct. at 890.

56. $\quad$ See id. at 878; Eldred, 537 U.S. at 218.

57. Harper \& Row, Publishers, Inc. v. Nation Enters., 471 U.S. 539, 541-42 (1985).

58. See id. at 555 ("Respondents, however, contend that First Amendment values require a different rule under the circumstances of this case.").

59. See Brief for Respondents at 43, Harper \& Row, Publishers, Inc. v. Nation Enters., 471 U.S. 539 (1985) (No. 83-1632), 1984 WL 565761, at *43.

60. Harper \& Row, 471 U.S. at 558.

61. See, e.g., Fisher v. Dees, 794 F.2d 432, 435 (9th Cir. 1982); Universal City Studios, Inc. v. Reimerdes, 82 F. Supp. 2d 211, 220 (S.D.N.Y. 2000) ("[T]he First Amendment does not shield copyright infringement.”); Chi. Sch. Reform Bd, of Trs. v. Substance, Inc., 79 F. Supp. 2d 919, 925 (N.D. Ill. 2000); Lish v. Harper's Magazine Found., 807 F. Supp. 1090, 1105 (S.D.N.Y. 1992).

62. See SunTrust Bank v. Houghton Mifflin Co., 252 F.3d 1165, 1166 (11th Cir.), vacated by 268 F.3d 1257 (2001).

63. See SunTrust Bank v. Houghton Mifflin Co., 268 F.3d 1257, 1276 (11th Cir. 2001).
} 
political campaign is protected by the First Amendment, the hesitation of courts to consider First Amendment arguments in the context of copyright infringement suits would counsel litigants to proceed on the basis of fair use. In fact, all of the decisions about copyright infringement in the context of political campaigns progress along these lines. ${ }^{64}$

It is important to note that defendants in copyright infringement suits face steep consequences. A finding of copyright infringement can result in the issuance of an injunction ${ }^{65}$ and the imposition of statutory damages that may far exceed any actual damages suffered by the copyright owner. ${ }^{66}$ Courts have avoided considering a First Amendment defense in the copyright infringement context by applying the Supreme Court's holding in eBay $v$. MercExchange, ${ }^{67}$ which requires an equitable four-factor analysis to determine whether the issuance of an injunction is appropriate. ${ }^{68}$ Prior to $e B a y$, once a copyright holder demonstrated infringement, courts presumed the likelihood of irreparable harm and, therefore, the issuance of injunctive relief was generally a foregone conclusion. ${ }^{69}$ It has been suggested that refusing to enjoin copyright infringement in some instances will serve to protect First Amendment interests. ${ }^{70}$

While applying eBay to make the issuance of injunctive relief less likely may help alleviate some First Amendment concerns, merely focusing on injunctive relief cannot fully address those concerns when the specter of damages of up to $\$ 150,000$ per infringement looms. In addition, the Copyright Act provides that the prevailing party may also recover attorney's fees and costs. ${ }^{71}$ This Article asserts that when the alleged infringement occurs in the context of a political campaign, the freedom of speech interests are so acute that resorting to the fair use doctrine or the idea-expression dichotomy is insufficient. Rather, courts should either approach the question from the First Amendment perspective or, at the very least, better incorporate First Amendment principles into the fair use analysis.

This Article will now consider the hypothetical case $N B C v$. Romney from the perspective of the First Amendment followed by an analysis under the Copyright Act. This side-by-side analysis calls into

\footnotetext{
64. See infra notes 184-194, 214-223 and accompanying text.

65. See 17 U.S.C. $\$ 502$ (2012).

66. See id. $\S 504$.

67. See eBay v. MercExchange, 547 U.S. 388, 391 (2006).

68. See Salinger v. Colting, 607 F.3d 68, 79 (2d Cir. 2010).

69. See, e.g., id. at 75-76 (explaining the Second Circuit's approach prior to eBay).

70. See Mark A. Lemley and Eugene Volokh, Freedom of Speech and Injunctions in Intellectual Property Cases, 48 DuKE L.J. 147, 182 (1998).

71. 17 U.S.C. $\$ 505$ (2012).
} 
question the assertion that Copyright's internal safeguards-namely, the idea-expression dichotomy and the affirmative defense of fair use-are sufficient to protect First Amendment interests.

\section{CONSIDERING NBC V. ROMNEY FROM THE PERSPECTIVE OF THE FIRST AMENDMENT}

As the Court made clear, "political speech [is] at the core of what the First Amendment is designed to protect."72 Before undertaking the substantive analysis of the fictional suit between Romney and NBC, it is important to note some points of First Amendment law. As an initial matter, the fact that the suit in question would occur between private litigants does not preclude First Amendment analysis. ${ }^{73}$ While there must be some state action in order for the First Amendment to apply, ${ }^{74}$ the enforcement of the Copyright Act constitutes such state action. ${ }^{75}$ Courts have entertained First Amendment arguments in defamation cases ${ }^{76}$ right of publicity cases ${ }^{77}$ and trademark cases. ${ }^{78}$ Moreover, in copyright cases that raised First Amendment arguments, no court refused to hear such arguments because of a lack of state action. ${ }^{79}$

Further, any assertion that the nature of copyright, being a private property interest, precludes First Amendment inquiry is untenable. First, the idea that copyright is, in fact, property is very much in dispute. ${ }^{80}$ Moreover, First Amendment jurisprudence provides any number of instances in which the asserted property

\footnotetext{
72. Virginia v. Black, 538 U.S. 343, 365 (2003).

73. See The N.Y. Times Co. v. Sullivan, 376 U.S. 254, 265 (1964).

74. See id. at 265 .

75. See id. ("Although this is a civil lawsuit between private parties, the Alabama courts have applied a state rule of law which petitioners claim to impose invalid restrictions on their constitutional freedoms of speech and press. It matters not that that law has been applied in a civil action and that it is common law only, though supplemented by statute. . . The test is not the form in which state power has been applied but, whatever the form, whether such power has in fact been exercised." (internal citations omitted)).

76. See id. at 266 .

77. See, e.g., Midler v. Ford Motor Co., 849 F.2d 460, 462 (9th Cir. 1988).

78. See, e.g., S.F. Arts \& Athletics, Inc. v. U.S. Olympic Comm., 483 U.S. 522, 535 (1987).

79. See supra notes 49-65 and accompanying text.

80. See William Patry, Moral PANICS AND the Copyright WARS 109-20 (2009) (explaining that the main difference between tangible property and copyrights arises from ex ante physical limitations on rights in the former and expansive, abstract ex post rights in the latter).
} 
interests of one party necessarily cede to the First Amendment rights of another. ${ }^{81}$

Having addressed these preliminary matters, this Article turns now to a consideration of whether the Romney campaign's use of the content in question ought to be privileged under the First Amendment.

\section{A. The Copyright Act, as Applied to the Use of Content in the Context of Political Campaigns, is Arguably Unconstitutionally Vague}

Some scholars have recently noted that the Copyright Act may be unconstitutionally vague. ${ }^{82}$ While one vein of this scholarship is limited to "the broad swath of copyright law in which the derivative works right intersects with the fair use doctrine," 83 the other sets out a general vagueness problem in the Copyright Act. ${ }^{84}$ That said, both recognize the problematically vague nature of the fair use defense, ${ }^{85}$ and both agree that it is unlikely that a court will find the Copyright Act, as a whole, void for vagueness. ${ }^{86}$

A statute is unconstitutionally vague when "men of common intelligence must necessarily guess at its meaning and differ as to its application." 87 A vague statute may run afoul of the First Amendment if it prohibits protected expression. ${ }^{88}$ In addition, reliance upon an affirmative defense to rescue an unconstitutional statute is necessarily problematic under the First Amendment. ${ }^{89}$

Political speech is not only protected expression; it receives the maximum protection under the First Amendment. ${ }^{90}$ While some courts have held that the First Amendment does not give an individual the right to copy another's speech, ${ }^{91}$ no court has yet considered the potential vagueness of the fair use defense as it applies to the use of copyrighted content in the context of a campaign for

\footnotetext{
81. See, e.g., Louis Michael Seidman, The Dale Problem: Property and Speech Under the Regulatory State, 75 U. CHI. L. REV. 1541, 1548 (2008) (collecting and analyzing cases).

82. See Bradley E. Abruzzi, Copyright and the Vagueness Doctrine, 45 U. MicH. J.L. REFORM 351, 366 (2012); Bohannan, supra note 45, at 683.

83. Bohannan, supra note 45 , at 672.

84. See Abruzzi, supra note 82, at 372.

85. See Bohannan, supra note 45, at 681-88; Abruzzi, supra note 82, at 377-81.

86. See Bohannan, supra note 45, at 692-94; Abruzzi, supra note 82, at 387.

87. Connally v. General Constr. Co., 269 U.S. 385, 391 (1926) (citing Int'l Harvester Co.

v. Kentucky, 234 U.S. 216, 221 (1914); Collins v. Kentucky, 234 U.S. 634, 638 (1914)).

88. $\quad$ See, e.g., Winters v. New York, 33 U.S. 507, 509 (1948).

89. See Bohannan, supra note 45 , at 681-82.

90. See supra notes 76-89 and accompanying text; infra notes 96-105 and accompanying text.

91. See Eldred v. Ashcroft, 537 U.S. 186, 221 (2003).
} 
political office. Examining the dispute between Romney and NBC may provide a road map for a litigant advancing a vagueness argument in this context.

As noted previously, all of the contemporaneous commentary about the Romney-NBC dispute concerned application of the fair use doctrine. ${ }^{92}$ While many commentators saw a clear case for fair use, ${ }^{93}$ one expert opined that Romney's fair use argument was anything but clear. ${ }^{94}$ This demonstrates that even the experts disagree over the application of the fair use doctrine in this context. Moreover, it is clear that Romney's advertisement is "speech uttered during a campaign for political office" and, as such, is entitled to the highest degree of protection under the First Amendment. ${ }^{95}$ Further consideration of the jurisprudence laying out the protection afforded campaign speech demonstrates that requiring Romney to engage in the fact-intensive project of proving that his use is a permissible fair use would run afoul of the First Amendment.

\section{B. Campaign Speech Has Long Enjoyed Special Protection Under the First Amendment}

The Supreme Court has long held that the First Amendment provides the greatest protection to speech concerning governmental affairs. ${ }^{96}$ In fact, in Eu v. San Francisco County Democratic Central Committee, the Court stated: "[T]he First Amendment 'has its fullest and most urgent application' to speech uttered during a campaign for political office." 97 Such speech is deemed necessary for self-government.98 According to the Court, "debate on the

\footnotetext{
92. See supra note 27 and accompanying text.

93. See e.g., Paulson, supra note 27; Seth Abramovitch, Is Romney's Tom Brokaw Ad 'Fair Use?', THE WIRE (Jan. 29, 2012, 10:00 AM), http://www.thewire.com/ politics/2012/01/romney-nbc-ad-fair-use/48013.

94. See Geri Haight, Copyright Lessons from the Campaign Trail: Romney, Gingrich and Fair Use, MinTz LEVIN: COPYRIGHT \& TRADEMARK MATTERS (Jan. 30, 2012), http://www.copyrighttrademarkmatters.com/2012/01/30/copyright-lessons-from-the-campaigntrail-romney-and-fair-use.

95. See William A. Williams, A Necessary Compromise: Protecting Electoral Integrity Through the Regulation of False Campaign Speech, 52 S.D. L. REV. 321, 349 (2007); infra notes 96-105 and accompanying text.

96. See Mills v. Alabama, 384 U.S. 214, 218 (1966) (“[T]here is practically universal agreement that a major purpose of . . . [the First] Amendment was to protect the free discussion of governmental affairs.").

97. Eu v. S.F. Cnty. Democratic Cent. Comm., 489 U.S. 214, 223 (1989) (quoting Monitor Patriot Co. v. Roy, 401 U.S. 265, 272 (1971)).

98. Connick v. Myers, 461 U.S. 138, 160 (1983) (“'[S]peech concerning public affairs is more than self-expression; it is the essence of self-government." (quoting Garrison v. Louisiana, 379 U.S. 64, 74-75 (1965)) (alteration in original)).
} 
qualifications of candidates [is] integral to the operation of the system of government established by our Constitution."99 Courts consistently hold restrictions on advertisements concerning both political issues and candidates unconstitutional under strict scrutiny. ${ }^{100}$ The Supreme Court's recent decision in Citizens United v. Federal Election Commission bears this out. ${ }^{101}$ In Citizens United, the Court specifically held that "political speech must prevail over law that would suppress it, whether by design or inadvertence."102 Although Citizens United deals with a very different statute, much of the language of the decision is arguably directly applicable to suits arising under the Copyright Act. For example:

The First Amendment does not permit laws that force speakers to retain a[n] ... attorney... or seek declaratory rulings before discussing the most salient political issues of our day... The Government may not render a ban on political speech constitutional by carving out a limited exemption . . . ${ }^{103}$

The Citizens United Court "decline[d] to adopt an interpretation that require[d] intricate case-by-case determinations to verify whether political speech is banned."104 The Court also pointed out that the very need for lawsuits commenced in the "heat of political campaigns" to determine whether certain speech is acceptable "stifle[s]" political speech. ${ }^{105}$

The advertisement at issue in our fictional suit between NBC and Romney certainly concerns governmental affairs. It is speech concerning the qualifications of a candidate for public office. As such, it ought to be accorded the highest degree of protection under the First Amendment. ${ }^{106}$ Under current case law, Romney's best option for escaping liability in a copyright infringement action would be a successful assertion of the fair use defense. ${ }^{107}$ But, such an approach would necessitate a case-by-case determination. ${ }^{108}$ The Supreme

\footnotetext{
99. Buckley v. Valeo, 424 U.S. 1, 14 (1976).

100. See, e.g., Fed. Election Comm'n, v. Wis. Right to Life, Inc., 551 U.S. 449, 464 (2007).

101. See, e.g., Citizens United v. Fed. Election Comm'n,, 558 U.S. 310, 340 (2010).

102. Id.

103. Id. at 324 .

104. Id. at 329 .

105. Id. at 334 .

106. See Terminiello v. City of Chicago, 337 U.S. 1, 4 (1949) ("The vitality of civil and political institutions in our society depends on free discussion. As Chief Justice Hughes wrote in De Jonge $v$. Oregon, it is only through free debate and free exchange of ideas that government remains responsive to the will of the people and peaceful change is effected. The right to speak freely and to promote diversity of ideas and programs is therefore one of the chief distinctions that sets us apart from totalitarian regimes." (internal citation omitted)).

107. See Harper \& Row, Publishers, Inc. v. Nation Enters., 471 U.S. 539, 560 (1985).

108. See Copyright Litigation HANDBOoK $§ 13: 22$ (2d ed. 2013)
} 
Court in Citizens United specifically stated that requiring such determinations in the heat of a campaign is impermissible under the First Amendment. ${ }^{109}$ As such, it seems clear that if the fictional case $N B C v$. Romney were approached from the perspective of the First Amendment, NBC would be unable to obtain injunctive relief. ${ }^{110}$ This, of course, leaves open the question of whether NBC ought to be entitled to damages.

\section{Allowing Any Remedy in these Circumstances Would Infringe the Constitutionally Protected Freedom to Listen}

Allegations of copyright infringement when the copyrighted content is used in the context of a political campaign not only implicate the First Amendment rights of the speaker but also offends those of the intended audience-the voting citizenry. It has long been recognized that First Amendment protections extend to the right of all of us to hear the exchange of information. ${ }^{111}$ In other words, "[s]ociety's interests in enjoying a transparent debate and in receiving information ... are paramount and are protected in conjunction with the speaker's interest in self-expression." 112 This right is particularly salient when the expression in dispute constitutes political speech. ${ }^{113}$ The very notion of self-government requires an informed electorate. ${ }^{114}$

Forcing a politician to pull an advertisement deprives the voting public of the politician's intended message. While some might argue that the Romney campaign could have simply recounted the facts stated in the NBC report, the question really is whether it ought to be required to do so. ${ }^{115}$ The value in reproducing the NBC content

109. Citizens United v. Fed. Election Comm’n, 558 U.S. 310, 333-34 (2010).

110. See id.; Near v. State of Minnesota ex rel. Olson., 283 U.S. 697, 737 (1931) (holding that enjoining protected speech is prohibited under the First Amendment); see also Lemley \& Volokh, supra note 70, at 205 (regarding the sufficiency of damages in copyright infringement cases).

111. See, e.g., Thornhill v. Alabama, 310 U.S. 88, 102 (1940) ("The exigencies of the colonial period and the efforts to secure freedom from oppressive administration developed a broadened conception of these liberties as adequate to supply the public need for information and education with respect to the significant issues of the times."); Stanley v. Georgia, 394 U.S. 557, 564 (1969) ("It is now well established that the Constitution protects the right to receive information and ideas. "This freedom (of speech and press) . . necessarily protects the right to receive ...." (quoting Martin v. City of Struthers, 319 U.S. 141, 143 (1943))).

112. Peter J. Ferrara \& Carlos S. Ramirez, The Constitutional Freedom to Listen, 6 LIBERTY U. L. REV 1, 5 (2011).

113. See, e.g., Buckley v. Valeo, 424 U.S. 1, 14 (1976).

114. See id.; Ferrara \& Ramirez, supra note 112, at 6-7.

115. See Randy Picker, Politics, Copyright and the First-Amendment Commons, THE University OF ChicAgo LAW School FACUlty Blog (Feb. 21, 2012, 9:07 PM), http://uchicagolaw.typepad.com/faculty/2012/02/politics-copyright-and-the-first-amendmentcommons.html. 
is more than merely recounting the asserted facts. The reproduction of the news report adds a stamp of objectivity to the facts. If the Romney campaign can use the footage, the voting public receives both the facts and the information that a respected news agency reported those facts. If news agencies as copyright owners can stop politicians from engaging in such uses, they can deprive voters of information relevant to the credibility and impact of statements. The message of the Romney campaign as embodied in its use of NBC's footage may be useful; indeed, respected news outlets reported on Gingrich's ethics problems. The Romney campaign would assert that those problems are relevant to voters' consideration of Gingrich as a candidate. The most salient means to convey the totality of that message is to reproduce the content of respected news agency. Utilizing the First Amendment as the appropriate frame for this question allows consideration of the interests of listeners, the voting public, as well as the political speakers.

Having considered the First Amendment arguments Romney might assert in a potential suit over his use of NBC's footage, this analysis moves on to consider whether the First Amendment rights of NBC might be implicated.

\section{Anticipating the First Amendment Offense: The Right Not to Speak, Compelled Speech, and Expressive Association}

Faced with a First Amendment defense to a copyright infringement suit, copyright owners have asserted a countervailing First Amendment interest in stopping the alleged infringement. ${ }^{116}$ Succinctly, the argument is that a failure to enjoin the alleged infringement constitutes a usurpation of the copyright owner's right not to speak. ${ }^{117}$ This line of argument has some basis in the case law. In Harper \& Row, the Supreme Court considered whether The Nation's use of short excerpts from the memoirs of President Ford to scoop an article constituted fair use. ${ }^{118}$ Concluding that the use was not a fair use, the Court stated, "[F] reedom of thought and expression includes both the right to speak freely and the right to refrain from

116. See Salinger v. Colting, 607 F.3d 68, 72 (2d Cir. 2010).

117. See Brief for Plaintiff-Appellee at 50, Salinger v. Colting, 607 F.3d 68 (2d Cir. 2010) (No. 09-2878-cv), 2009 WL 6865323, at *50 ("Salinger's constitutionally based right not to publish derivatives is not the type of injury that can adequately be remedied by monetary damages; it is exactly the kind of damage that courts traditionally find irreparable. Indeed, this Court has reversed a lower court for failing to issue a preliminary injunction in a case involving the right not to speak, citing the many cases to that effect." (citing Int'l Dairy Foods Ass'n v. Amestoy, 92 F.3d 67, 71 (2d Cir. 1996))).

118. See Harper \& Row, Publishers, Inc. v. Nation Enters., 471 U.S. 539, 560-69 (1985). 
speaking at all."119 For this proposition, the Court relied upon Wooley v. Maynard, in which a New Hampshire statute requiring the display of the state motto "Live Free or Die" was held to infringe upon Maynard's right not to speak. ${ }^{120}$ In Harper \& Row the Court went on to say, "Courts and commentators have recognized that copyright, and the right of first publication in particular, serve this countervailing First Amendment value."121

More recently, in Salinger $v$. Colting the United States Court of Appeals for the Second Circuit stated, "The plaintiff's interest is, principally, a property interest in the copyrighted material... [b]ut ... a copyright holder might also have a First Amendment interest in not speaking." 122 Salinger dealt with whether the trial court erred in issuing an injunction against the publication of 60 Years Later: Coming Through the Rye, a novel by Frederik Colting. ${ }^{123}$ Colting's novel purported to tell the story of J.D. Salinger's famous character, Holden Caulfield, sixty years after the events that occurred in The Catcher in the Rye. ${ }^{124}$ The Second Circuit considered whether the Plaintiff's right not to speak might be implicated where the Defendant wrote an allegedly infringing sequel to the Plaintiff's copyrighted work. The allegedly infringing work did not copy Salinger's novel. Rather, Salinger alleged that Colting's novel constituted an unauthorized sequel to The Catcher in the Rye. ${ }^{125}$ The plaintiffs asserted that publication of Colting's novel would cause irreparable harm by infringing upon their right not to speak. ${ }^{126}$ Although the Second Circuit remanded the case for consideration of the issue of irreparable harm, the Court explained that "infringement of the right not to speak, 'for even minimal periods of time, unquestionably constitutes irreparable injury."'127

Although Harper \& Row and Salinger relied nearly exclusively on Wooley as the conceptual basis for a copyright owner's First Amendment right, Wooley is in a line of Supreme Court precedent that requires some exegesis to fully understand the ill-fit of the right not to speak and related concepts in the context of copyright infringement

119. Id. at 559 (quoting Wooley v. Maynard, 430 U.S. 705, 714 (1977)).

120. See 430 U.S. at 717.

121. Harper \& Row, 471 U.S. at 560 (citing Schnapper v. Foley, 667 F.2d 102 (1981)).

122. Salinger v. Colting, 607 F.3d 68, 81 (2d Cir. 2010) (citing Wheaton v. Peters, 33 U.S. (8 Pet.) 591, 661 (1834); Harper \& Row, Publishers, Inc. v. Nation Enters., 471 U.S. 539, 559 (1985)).

123. Salinger, 607 F.3d at 74-75.

124. Id. at 71 .

125. See id. at 72.

126. See id. at 81 .

127. Id. (quoting Elrod v. Burns, 427 U.S. 347, 373 (1976)). 
suits. ${ }^{128}$ The Court has broadly described the right not to speak: "[G]overnment may not force individuals to utter or convey messages they disagree with or, indeed, to say anything at all." 129 This right is said to be protective of "a speaker['s] ... autonomy to choose the content of his own message." 130

The right not to speak is broad enough to prohibit the government from requiring an individual to convey the government's message and from requiring an individual to convey a third party's message. ${ }^{131}$ Pacific Gas \& Electric Co. v. Public Utilities Commission of California demonstrated the latter. The Court held that an order of the California Public Utilities Commission requiring the plaintiff to include a newsletter published by another entity in its customer billing mailings infringed upon the company's First Amendment rights. ${ }^{132}$ Specifically the Court stated:

The Commission's order forces appellant to disseminate... speech in envelopes that appellant owns and that bear appellant's return address. Such forced association with potentially hostile views burdens the expression of [different] views . . . and risks forcing appellant to speak where it would prefer to remain silent. ${ }^{133}$

As such, Pacific Gas \& Electric Co. might be placed in the line of expressive association cases that stands for the proposition that the First Amendment prohibits the government from requiring organizations to include certain messages in their expressive conduct. ${ }^{134}$

The vast majority of expressive association cases arise from scenarios like the following: An individual seeks inclusion in an organization on the basis of some anti-discrimination statute. The organization responds by asserting that such inclusion abridges its expressive association rights by requiring it to convey a message it does not wish to. ${ }^{135}$

128. See Rumsfeld v. Forum for Academic and Institutional Rights, Inc., 547 U.S. 47, 61 (2006); Hurley v. Irish-Am. Gay, Lesbian and Bisexual Group of Bos., 515 U.S. 557, 573 (1995); Pac. Gas \& Elec. Co. v. Pub. Utilities Comm'n of Cal., 475 U.S. 1, 32 (1986); PruneYard Shopping Ctr. v. Robins, 447 U.S. 74, 99 (1980); Miami Herald Publ'g Co. v. Tornillo, 418 U.S. 241, 256 (1974) W. Va. State Bd. of Educ. v. Barnette, 319 U.S. 624, 645 (1943).

129. Johanns v. Livestock Mktg. Ass'n, 544 U.S. 550, 573 (2005).

130. Hurley, 515 U.S. at 573.

131. See Johanns, 544 U.S. at 573.

132. See Pac. Gas \& Elec. Co., 475 U.S. at 20-21.

133. Id. at 18 .

134. For an explication of the concept of expressive association, see, for example, Dale Carpenter, Expressive Association and Anti-Discrimination Law After Dale: A Tripartite Approach, 85 MinN. L. REV. 1515, 1534-35 (2001).

135. See, e.g., Roberts v. U.S. Jaycees, 468 U.S. 609, 615 (1984). 
Neither the right not to speak-at issue in Wooley and Pacific Gas \& Electric Co.--nor the right of expressive association is a perfect fit for the assertion made by copyright holders. As an initial matter, the foundation of all of these is that the speaker should not be forced to convey a message with which he or she does not agree. ${ }^{136}$ In copyright infringement cases such as the NBC $v$. Romney hypothetical, NBC is not forced to say anything; rather, its words are merely copied. ${ }^{137}$ Moreover, while the right of expressive association may superficially appear to have some relevance, it is important to note that those cases consider the validity of the application of some statute to require one speaker to include the message of another in its speech. ${ }^{138}$ Here, NBC seeks to exclude its speech from Romney's campaign advertisements. There is simply no reading of the expressive association cases that grants NBC this degree of control over the content of Romney's message.

Even if one believes that these concepts have some relevance in copyright infringement suits, it is important to recall that the decision in Harper \& Row, which read the right not to speak into copyright jurisprudence, was based, at least in part, on the right of first publication. ${ }^{139}$ Undergirding the right not to speak was a privacy interest that had previously inhered in common law copyright holders prior to publication. ${ }^{140}$ In his seminal article, Nimmer aptly notes that cases in which the content in question has already been published implicate no such privacy interest. ${ }^{141}$

It is difficult to comprehend how publication of Colting's novel could be perceived as a compulsion of speech by Salinger analogous to the government compulsion to express a particular viewpoint considered in Wooley. ${ }^{142}$ It is also clear that the facts presented in Salinger were markedly different from those in Harper \& Row. In Salinger, the alleged infringement was the writing and publication of a sequel rather than the copying and scooping of an important portion of a text prepublication, as was the case in Harper \& Row. Nonetheless, the Second Circuit found that the dispute over

136. See supra notes 130-133 and accompanying text.

137. For a philosophical argument that all copyright infringement constitutes compelled speech in derogation of the copyright owner's autonomy, see Abraham Drassinower, Copyright Infringement as Compelled Speech, in NeW Frontiers IN THE PHILOSOPHY OF INTELLECTUAL PROPERTY (Annabelle Lever ed., 2012).

138. See supra notes 130-135 and accompanying text.

139. See Harper \& Row, Publishers, Inc. v. Nation Enters., 471 U.S. 539, 560 (1985).

140. See Pac. Gas \& Elec. Co. v. Pub. Utilities Comm'n of Cal., 475 U.S. 1, 34 (1986) (Rehnquist, J., dissenting).

141. See Nimmer, supra note 35, at 1191

142. See Deidré A. Keller, Recognizing the Derivative Works Right as a Moral Right: A Case Comparison and Proposal, 63 CASE W. RES. L. REv. 511, 536-38 (2013). 
publication of 60 Years Later: Coming Through the Rye implicated the right not to speak. ${ }^{143}$ That decision was inconsistent with both the First Amendment jurisprudence underlying the right not to speak and the case extending that concept into copyright.

In a suit between Romney and NBC over the Romney campaign's use of NBC's footage, basing a finding for NBC on the right not to speak would be tantamount to saying that NBC has the right not to speak in certain contexts or the right not to have its speech associated with a particular candidate or party. NBC, in its televised broadcast, had already spoken. The only remaining question is whether NBC should be able to stop the Romney campaign from repeating that speech to further its political objectives. Does NBC have the right to control the content of Romney's political message through the assertion of its copyright? In a sense, answering this question requires consideration of whether we privilege NBC's copyright or Romney's right to convey his political message in the manner of his choosing. In other words, a satisfactory answer requires us to squarely address the issues that arise when the proprietary interests of copyright meet the free speech interests embodied in the First Amendment.

\section{THE COPYRIGHT APPROACH TO NBC V. ROMNEY: DO THE INTERNAL SAFEGUARDS PROTECT THE FIRST AMENDMENT INTERESTS?}

Courts have consistently held that First Amendment scrutiny in the context of copyright infringement suits is unnecessary. ${ }^{144}$

143. See Salinger v. Colting, 607 F.3d 68, 81-82 (2d Cir. 2010).

144. See, e.g., Walt Disney Prods. v. Air Pirates, 581 F.2d 751, 758-59 (9th Cir. 1978), cert. denied, 439 U.S. 1132 (1979) ("[D]efendants' [First Amendment] claim can be dismissed without a lengthy discussion . . ..”); Ass'n of Am. Med. Colls. v. Princeton Review, Inc., 332 F. Supp. 2d 11, 20 (D.D.C. 2004) ("The First Amendment does not require that copyrighted works be published or made available to particular persons." (citing Stewart, 495 U.S. 207, 228-29 (1990))); Video Pipeline, Inc. v. Buena Vista Home Entm't, Inc., 192 F. Supp. 2d 321, 346-47 (D.N.J. 2002) (rejecting the Defendant's First Amendment argument holding, "[c]opyright laws are thus not restrictions on speech, as "copyright laws, of course, protect only the form of expression and not the ideas expressed." (quoting N.Y. Times Co. v. United States, 403 U.S. 713, 726 (1971) (Brennan, J., concurring))); Lish v. Harper's Magazine Found., 807 F. Supp. 1090, 1105 (S.D.N.Y. 1992) (holding that the idea-expression dichotomy and fair use are sufficient to protect any First Amendment interests not fully alleviated by the ability to quote purely factual information); Consumer Union of the U.S., Inc. v. The New Regina Corp., 664 F. Supp. 753, 761 n.10 (S.D.N.Y. 1987) (rejecting Defendant's First Amendment argument stating "[t]he idea/expression dichotomy embodied in copyright 'strike[s] a definitional balance between the First Amendment and the Copyright Act by permitting free communication of facts while still protecting an author's expression." (quoting Harper \& Row, Publishers, Inc. v. Nation Enters., 471 U.S. 539, 556 (1985))); United States v. Bodin, 375 F. Supp. 1265, 1267-68 (W.D. Okla. 1974) ("We fail to see as any protected first amendment right a privilege to usurp the benefits [of the copyright holder's efforts].”). 
According to the Supreme Court, “copyright's idea/expression dichotomy 'strike[s] a definitional balance between the First Amendment and the Copyright Act by permitting free communication of facts while still protecting an author's expression."'145 The D.C. Circuit later stated, "copyrights are categorically immune from challenges under the First Amendment."146 While the Supreme Court has articulated a more nuanced approach, ${ }^{147}$ its recent decision in Golan seems to support the notion that the application of the First Amendment in the context of copyright cases is only appropriate when the idea-expression dichotomy and fair use fail to protect the free speech interests. ${ }^{148}$ Therefore, any assertion that a court ought to approach a copyright suit from the perspective of the First Amendment must begin with a consideration of the viability of these internal safeguards.

\section{A. Idea-Expression Dichotomy: Considering the Copyrightability of News and Infringement by Reproduction}

The first aspect of copyright law asserted as protective of First Amendment interests is the idea-expression dichotomy. ${ }^{149}$ The idea-expression dichotomy began as a judge-made principle. ${ }^{150}$ In 1880 , the case Baker $v$. Selden ${ }^{151}$ introduced the concept to American law. ${ }^{152}$ Section 102(b) of the Copyright Act codified the ideaexpression dichotomy, stating: "In no case does copyright protection for an original work of authorship extend to any idea, procedure, process, system, method of operation, concept, principle, or discovery, regardless of the form in which it is described, explained, illustrated, or embodied in such work." 153 The inclusion of the word "discovery" in

145. Harper \& Row, Publishers, Inc. v. Nation Enters., 471 U.S 539, 556 (1985) (quoting Harper \& Row, Publishers, Inc. v. Nation Enters., 723 F.2d 195, 203 (2d Cir. 1983), rev'd, 471 U.S. 539 (1985)).

146. $\quad$ Eldred v. Reno, 239 F.3d 372, 375 (D.C. Cir. 2001), aff'd, 537 U.S. 186 (2003).

147. See Eldred v. Reno, 537 U.S. 186, 221 (2003) ("We recognize that the D.C. Circuit spoke too broadly when it declared copyrights 'categorically immune from challenges under the First Amendment."' (quoting Eldred v. Reno, 239 F.3d at 375)).

148. See Golan v. Holder, 132 S. Ct. 873, 890 (2012) (describing the traditional contours of copyright as the idea-expression dichotomy and the fair use defense and noting that the Tenth Circuit's broader reading of the term was incorrect).

149. See id.

150. See Edward Samuels, The Idea-Expression Dichotomy in Copyright Law, 56 TenN. L. REV. 321, 325 (1989).

151. 101 U.S. 99 (1880).

152. See Samuels, supra note 150, at 326 ("The idea-expression dichotomy in America is said to have originated in the United States Supreme Court case of Baker v. Selden.”).

153. 17 U.S.C. $§ 102(b)(2012)$. 
the statute demonstrates that copyright does not extend to the facts contained in an otherwise copyrightable work. ${ }^{154}$

It has long been held that the facts conveyed in a news report are "publici juris; . . . the history of the day." 155 In International News Service v. Associated Press, ${ }^{156}$ the Supreme Court said:

\footnotetext{
It is not to be supposed that the framers of the Constitution, when they empowered Congress "to promote the progress of science and useful arts, by securing for limited times to authors and inventors the exclusive right to their respective writings and discoveries" (Const., art. I, § 8, par. 8), intended to confer upon one who might happen to be the first to report a historic event the exclusive right for any period to spread the knowledge of it. ${ }^{157}$
}

However, the form of the news report is copyrightable. ${ }^{158}$ This is true whether the news is in the form of an $\operatorname{article}^{159}$ or a television broadcast. ${ }^{160}$

It is important to note that, while courts often hail the idea-expression dichotomy as one of the safeguards that protect First Amendment interests, in cases raising the First Amendment as a defense to infringement courts tend to disregard the concept almost entirely and rely instead on the fair use defense. ${ }^{161}$ If the alleged infringing content is an exact reproduction of the copyrighted content, the idea-expression dichotomy can only mitigate a finding of infringement if the merger doctrine applies. ${ }^{162}$ The merger doctrine

154. See 2 Melville B. Nimmer \& DAVID Nimmer, Nimmer on Copyright $§ 2.11$ (Matthew Bender, rev. ed.). Another way of articulating the same concept, that facts are not copyrightable, is by making reference to the Copyright Act's definition of copyrightable subject matter as "original works of authorship." See 17 U.S.C § 102(a) (emphasis added). See, e.g., Feist Publ'n, Inc. v. Rural Tel. Serv., Co., 499 U.S. 340, 363 (1991) (finding that a white pages directory was not copyrightable because it merely reproduced existing facts in an unoriginal manner, that is in alphabetical order). This article addresses this concept by way of reference to the idea-expression dichotomy because courts routinely make reference to the dichotomy as one of the two internal safeguards for First Amendment concerns. Id. at 350.

155. Int'l News Serv. v. Associated Press, 248 U.S. 215, 234 (1918) (emphasis added).

156. Id.

157. $I d$.

158. See Wainwright Sec., Inc. v. Wall St. Transcript Corp., 558 F.2d 91, 95-96 (2d Cir. 1977).

159. See id. at 95 .

160. See, e.g., Ga. TV Co. v. TV News Clips, Inc., 718 F. Supp. 939, 946 (N.D. Ga. 1989) ("[C]opyright protection attaches to the broadcast feature only when the first copy of the transmission is made.").

161. See, e.g., Suntrust Bank v. Houghton Mifflin Co., 268 F.3d 1257, 1260 (2001); Salinger v. Colting, 607 F.3d 68, 83 (2010). Note also, that none of the decisions in which a claim of copyright infringement is asserted in the context of a political campaign includes any discussion of the idea expression dichotomy. See infra notes 184-194, 214-223 and accompanying text.

162. See, e.g., Scott Abrahamson, Seen One, Seen Them All? Making Sense of the Copyright Merger Doctrine, 45 UCLA L. REV. 1125, 1126-27 (1998). 
applies when there are so few possible forms of expression for a particular idea that the idea and expression merge. ${ }^{163}$ Some commentators and courts have questioned whether the merger doctrine ought to apply to visual works at all. ${ }^{164}$

Many academics have considered whether the idea-expression dichotomy functions to advance First Amendment interests. ${ }^{165}$ But would the idea-expression dichotomy allow the Romney campaign to use the content in question in this fictional case? The foregoing brief review of idea-expression jurisprudence demonstrates that the answer to that inquiry is, simply, no. As an initial matter, the content in question, though based upon facts, is copyrightable. ${ }^{166}$ The idea-expression dichotomy cannot assist in the infringement analysis because Romney used an exact reproduction of the copyrighted content, and the merger doctrine, which has not yet allowed the copying of a television news broadcast, is unlikely to be helpful.

Some might argue that even if the idea-expression dichotomy is unlikely to serve as a defense after the fact, it ought to have been instructive to the Romney campaign beforehand. That is, the idea-expression dichotomy delineated what the campaign could do-utilize the facts reported in NBC's broadcast-and what it could not do-reproduce, distribute, or display the broadcast itself. However, whether Romney could have gotten around the potential copyright problem is not at issue here; the question is whether the Copyright Act should operate to require him to do so. Once the campaign chooses to utilize the footage, should NBC have the ability to use its copyright to enjoin the campaign from doing so or recover damages for that use? If we believe that speech undertaken in the context of political campaigns is deserving of the greatest degree of freedom then the answer to this question must be no. In order to determine whether a court approaching this issue would arrive at that answer, we must consider the merits of the infringement analysis.

\section{B. The Infringement Analysis}

Section 106 of the Copyright Act grants the exclusive rights of reproduction, distribution, and public display, among others, to the

163. See id. at 1126 .

164. See Michael D. Murray, Copyright, Originality, and the End of Scènes à Faire and Merger Doctrines for Visual Works, 58 BAYLOR L. REV. 779, 787, 858 (2006) ("[T]here are myriad possible ways to express ideas visually ....”).

165. See, e.g., Alfred C. Yen, A First Amendment Perspective on the Idea/Expression Dichotomy and Copyright in a Work's "Total Concept and Feel," 38 EMORY L.J. 393, 396-97 (1989).

166. See supra Part IV.A. 
copyright owner. ${ }^{167}$ One need not copy the entire copyrighted work to be liable for infringement. ${ }^{168}$ In fact, there is no bright line rule as to what portion of a copyrighted work an alleged infringer must reproduce to result in a finding of infringement. 169 Rather, courts consider both quantitative and qualitative taking; that is what portion of the content was taken and how important the portion copied was, relative to the remainder of the work. ${ }^{170}$

There is no question that the Romney campaign reproduced a portion of the NBC broadcast without its authorization. Although the advertisement only utilized thirty seconds of the broadcast, because there is no definitive amount of content which must be taken in order for there to be a finding of infringement, it is entirely possible that the advertisement in question would be found to infringe NBC's exclusive rights.

\section{Fair Use}

Fair use, like the idea-expression dichotomy, is a common law principle. ${ }^{171}$ Folsom $v$. Marsh was the first US case to apply the principle. ${ }^{172}$ The 1976 Act first codified fair use in the statute. ${ }^{173}$ Section 107 of the statute reads:

[T] he fair use of a copyrighted work ... is not an infringement of copyright. In determining whether the use made of a work in any particular case is a fair use the factors to be considered shall include-

(1) the purpose and character of the use, including whether such use is of a commercial nature or is for nonprofit educational purposes;

(2) the nature of the copyrighted work;

167. 17 U.S.C. $\$ 106$ (2012).

168. See, e.g., Iowa State Univ. Research Found., Inc. v. Am. Broad. Cos., Inc., 463 F. Supp. 902, 903 (S.D.N.Y. 1978).

169. See Ringgold v. Black Entm't Television, Inc., 126 F.3d 70, 74-77 (2d Cir. 1997) (explaining the concept of de minimis taking in the context of copyright infringement and ultimately holding that the appearance of some portion of Plaintiff's poster in a total of less than thirty seconds of the television show in question was not a de minimis taking); see also Bridgeport Music, Inc. v. Dimension Films, 410 F.3d 792, 801-02 (6th Cir. 2005) (holding that the sampling of two seconds of a song constituted actionable infringement); Fisher v. Dees, 794 F.2d 432, 434 n.2 (9th Cir. 1986) ("[A] taking is considered de minimis only if it is so meager and fragmentary that the average audience would not recognize the appropriation." (citing Elsemere Music, Inc. v. Nat'l Broad. Co., 482 F. Supp. 741, 744 (S.D.N.Y. 1980))). For a recent analysis of the development of the de minimis doctrine, see Peter S. Menell and Ben Depoorter, Using Fee Shifting to Promote Fair Use and Fair Licensing, 102 CAL. L. REV. 53, 63-64 (2014).

170. Bridgeport Music, Inc., 410 F.3d at 797-98.

171. See Sony Corp. of Am. v. Universal City Studios, Inc., 464 U.S. 417, 475 n.27 (1984) (describing the history of the fair use doctrine in American case law).

172. 9 F. Cas. 342, 345, 348 (C.C.D. Mass. 1841) (No. 4901).

173. 17 U.S.C. $\S 107$ (2012). 
(3) the amount and substantiality of the portion used in relation to the copyrighted work as a whole; and

(4) the effect of the use upon the potential market for or value of the copyrighted work. ${ }^{174}$

Although the listed factors are nonexhaustive, they tend to predominate courts' fair use decisions. ${ }^{175}$ Fair use is an affirmative defense. ${ }^{176}$ Moreover, fair use is a mixed question of law and fact, ${ }^{177}$ which requires case-by-case analysis. ${ }^{178}$ Given the fact-sensitive nature of the fair use inquiry, courts have long held that summary adjudication of fair use is improper. ${ }^{179}$

\section{The Purpose and Character of the Use}

To determine whether this factor favors the copyright owner or the alleged infringer, courts often consider (1) whether the use is commercial or for nonprofit or educational purposes ${ }^{180}$ and (2) whether the use is transformative. ${ }^{181}$ The nonprofit nature of the alleged infringement is not dispositive. ${ }^{182}$

Courts have split on the issue of whether the use of a copyrighted work in a political campaign is commercial for purposes of the fair use analysis. In Keep Thomson Governor Committee $v$. Citizens for Gallen Committee, ${ }^{183}$ the United States District Court for the District of New Hampshire considered whether the Defendant's campaign advertisement, which incorporated fifteen seconds of Plaintiff's song, constituted copyright infringement. ${ }^{184}$ The Defendant asserted that its use constituted fair use. ${ }^{185}$ Regarding the character

174. Id.

175. See Barton Beebe, An Empirical Study of U.S. Copyright Fair Use Opinions, 19782005, 156 U. PA. L. REV. 549, 561-64 (2008).

176. See Campbell v. Acuff-Rose Music, 510 U.S. 569, 590 (1994). For a full explication of how fair use came to be understood as an affirmative defense in American law, see Ned Snow, The Forgotten Right of Fair Use, 62 CASE W. RES. L. REV. 135, 159-60 (2011).

177. See Harper \& Row, Publishers, Inc. v. Nation Enters., 471 U.S. 539, 560 (1985).

178. See id. at 549 .

179. See, e.g., DC Comics Inc. v. Reel Fantasy, Inc., 696 F.2d 24, 28 (2d Cir. 1982 ) ("The four factors listed in Section 107 raise essentially factual issues and, as the district court correctly noted, are normally questions for the jury.”); see also Meeropol v. Nizer, 560 F.2d 1061, 1069 (2d Cir. 1977). But see Mattel Inc. v. Walking Mountain Prods., 353 F.3d 792, 800 (9th Cir. 2003) ("Where material facts are not in dispute, fair use is appropriately decided on summary judgment." (citing Harper \& Row, Publishers, Inc., 471 U.S. at 560)).

180. See Harper \& Row, Publishers, Inc., 471 U.S. at 562.

181. See Campbell, 510 U.S. at 587-88.

182. Id. at 584 ("[T]he mere fact that a use is educational and not for profit does not insulate it from a finding of infringement ....").

183. 457 F. Supp. 957 (D.N.H. 1978).

184. Id.

185. See id. at 960 . 
of the use, the Court stated, "The use by the defendant ... is clearly part of a political campaign message, noncommercial in nature . ..."186 Nearly thirty years later, the United States District Court for the Southern District of New York also concluded that the use of copyrighted content in the context of a political advertisement was not commercial. ${ }^{187}$ More recently, the United States District Court for the Central District of California came to the opposite conclusion. ${ }^{188}$ In Henley v. Devore, ${ }^{189}$ the court considered whether the use of two copyrighted songs in political advertisements constituted fair use. ${ }^{190}$ The court acknowledged the prior precedent but explained that, "in the Ninth Circuit 'monetary gain is not the sole criterion[,] particularly in a setting where profit is ill-measured in dollars."' 191 The court went on to say that the defendants "stood to gain publicity and campaign donations from their use of" the copyrighted songs; ${ }^{192}$ therefore, the use was commercial. 193

A use is transformative if it serves a purpose different from the copyrighted work. ${ }^{194}$ In this sense, this factor overlaps with the effect on the market of the work because a transformative work will not act as a market substitute for the copyrighted work. ${ }^{195}$ The classic case of a transformative use is a parody using a copyrighted work as the basis for the creation of a new work. ${ }^{196}$ In Campbell v. Acuff Rose, ${ }^{197}$ the Supreme Court held that a parody of Roy Orbison's song "Oh, Pretty Woman" was a fair use. ${ }^{198}$ In Campbell, the Court defined a parody as "the use of some elements of a prior author's composition to create a new one that, at least in part, comments on that author's works." 199 The Court assumed that the goal of any parody is to amuse its audience, ${ }^{200}$ even if the joke might not be to the Court's taste. ${ }^{201}$

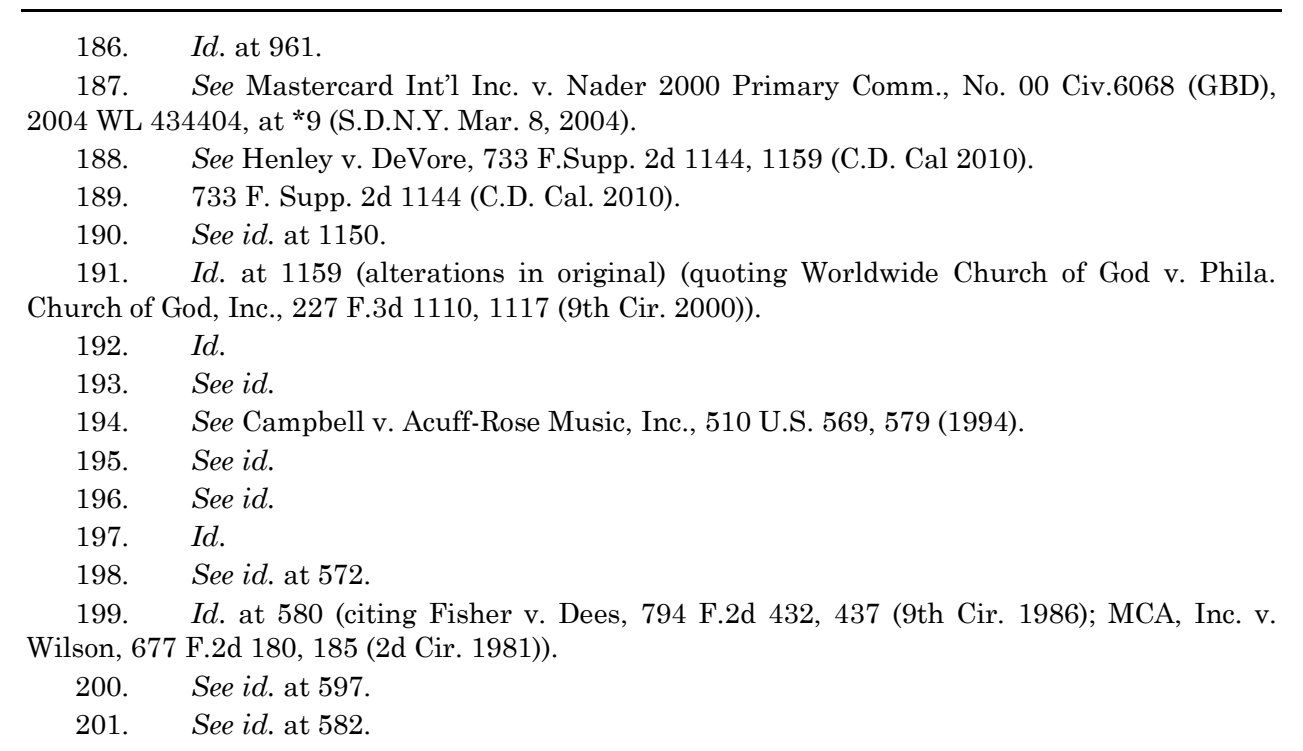


The Romney ad is obviously not a parody. First, the advertisement does not comment upon the NBC broadcast. Rather, it comments on the subject of that broadcast-Newt Gingrich. Moreover, the advertisement consists solely of the snippet in question, adding no new content. Its goal is not humor. Although the Supreme Court has cautioned against declining to find fair use just because the court does not get the joke, it seems clear on its face that there is no joke intended here.

Since Campbell, a number of lower courts have found transformative uses outside of the context of parody. In both Kelly $v$. Arriba Soft Corp. ${ }^{202}$ and Perfect 10, Inc. v. Amazon.com, Inc., ${ }^{203}$ the Ninth Circuit held that the alleged infringer engaged in transformative use when it provided thumbnails of the copyright owner's images in its search engine results. ${ }^{204}$ In Núñez v. Caribbean International News Corp., ${ }^{205}$ the United States Court of Appeals for the First Circuit held that a newspaper's use of a photograph of a model originally taken as a part of her portfolio was a transformative use because that use did not interfere with the market for the photograph as a portion of a fashion portfolio. ${ }^{206}$ Similarly, the United States Court of Appeals for the Second Circuit has held that the use of concert posters in a book detailing the history of a band was a transformative fair use. ${ }^{207}$

If NBC's purpose is articulated broadly (e.g., providing information to the polity), there is a colorable argument that Romney's use would fall within this ambit. While NBC's motivation behind providing the information about Gingrich's ethics dilemmas might be completely different from Romney's, there is a way in which the asserted purposes may overlap. To find otherwise, a court would have to consider and credit Romney's political motivations.

Framed within the context of Romney's campaign for office, it seems clear that Romney's advertisement serves a purpose quite different from NBC's purpose in producing the original, underlying content. While NBC's purpose in publishing the broadcast was the contemporaneous dissemination of newsworthy facts, Romney's is the dissemination of a political message designed to aid his quest to obtain the Republican nomination for the Presidency. While asserting the precise nature of that political message requires some speculation,

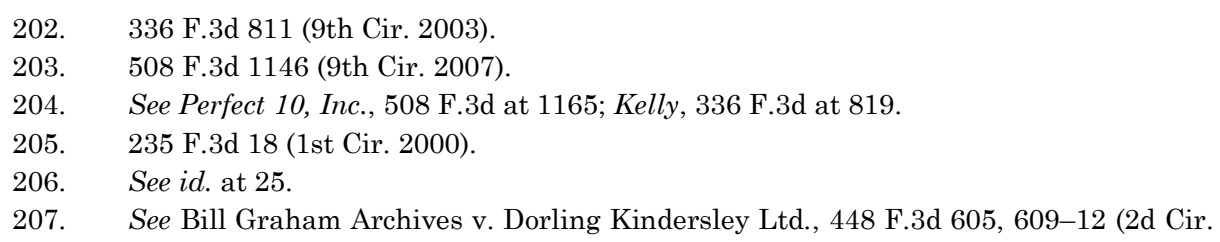


there is no question that Romney's purpose was not the contemporaneous dissemination of newsworthy facts. As an initial matter, the events underlying the broadcast took place some fifteen years prior to the Romney advertisement. ${ }^{208}$ As such, the purpose of Romney's use is distinct from that of NBC's initial production of the broadcast. ${ }^{209}$

To the extent that a court hearing a copyright infringement suit will consider the First Amendment as a limit upon copyright, it will generally do so based on the nature of the alleged infringer's use. ${ }^{210}$ A number of courts have held that a use involving content that is of great public concern weighs in favor of the alleged infringer. ${ }^{211}$ Moreover, courts have held that where a case implicates the First Amendment, the fair use doctrine is to be given a wider reading. ${ }^{212}$ However, no court has ever held that the use of copyrighted content in a campaign advertisement is fair use as a matter of law. In fact, in Browne v. McCain, ${ }^{213}$ the McCain presidential campaign filed a motion to dismiss, asserting that use of the song "Running on Empty" in its advertisement constituted fair use as a matter of law. ${ }^{214}$ The Central District of California denied the motion explaining,

[The Republican National Committee] has not established that Plaintiff's claim is barred, as a matter of law, under the fair use doctrine. The mere fact that Plaintiff's claim is based on Defendants' use of his copyrighted work in a political campaign does not bar Plaintiff's claim as a matter of law. ${ }^{215}$

208. See Jack Mirkinson, NBC Demands Mitt Romney Take Down Ad That Uses Tom Brokaw Footage, The Huffington Post (Jan. 28, 2012, 1:14 PM, updated Jan. 28, 2012, 4:50 PM), http://www.huffingtonpost.com/2012/01/28/nbc-mitt-romney-tom-brokaw-ad_n_1239107. html.

209. See Int'l News Serv. v. Associated Press, 248 U.S. 215 (1918).

210. See, e.g., Nat'l Rifle Ass'n of Am. v. Handgun Control Fed'n of Ohio, 15 F.3d 559, 562 (6th Cir. 1994) ("This contrast with commercial activity helps show that the purpose and character of HCF's use is far removed from that which the copyright law centrally protects and instead falls within the realm of the designated fair use purposes. The document was used primarily in exercising HCF's First Amendment speech rights to comment on public issues and to petition the government regarding legislation.").

211. See id. ("The scope of the fair use doctrine is wider when the use relates to issues of public concern." (citing Consumers Union of U.S., Inc. v. Gen. Signal Corp., 724 F.2d 1044, 1040 (2d Cir. 1983))); see also Hustler Magazine v. Moral Majority, 606 F. Supp. 1526, 1526-36 (C.D. Cal. 1985).

212. See, e.g., Wojnarowicz v. Am. Family Ass'n, 745 F. Supp. 130, 146-47 (S.D.N.Y. 1990).

213. 612 F. Supp. 2d 1125 (C.D. Cal. 2009).

214. See id. at 1129-30.

215. Id. at 1130 . 
The McCain campaign ultimately settled the litigation. ${ }^{216}$ Likewise, in Long $v$. Ballantine, ${ }^{217}$ the United States District Court for the Eastern District of North Carolina denied an alleged infringer's motion for judgment as a matter of law on the issue of fair use where the defendant used plaintiff's photograph in the context of a campaign advertisement. ${ }^{218}$ The Long court specifically held that fair use is determined on a case-by-case basis, and, therefore, the determination of this issue at trial was dispositive. ${ }^{219}$ The Long decision also highlights an additional risk an alleged infringer in a copyright infringement suit faces - the award of attorney's fees and costs. ${ }^{220}$ Even though the jury only awarded damages of $\$ 500,221$ the plaintiff was able to recover over $\$ 70,000$ in attorney's fees and costs. ${ }^{222}$ Such decisions give any potential copyright defendant pause.

In the absence of a more robust consideration of the First Amendment interests at stake, a court would likely find that the use of NBC's copyrighted footage by the Romney campaign is a commercial use. The question of transformativeness, however, is a mixed bag given the mere copying without parody (weighing in favor of NBC) but the arguably different purpose from the original use (weighing in favor of the Romney campaign). Ultimately, the "purpose and character of use" likely weighs slightly in favor of NBC or is neutral.

\section{The Nature of the Copyrighted Work}

Courts have held that the nature of the copyrighted work is of the least import in the fair use analysis. ${ }^{223}$ When considering this factor, courts ask whether the copyrighted work is the type of work that is at the heart of copyright protection, such as a fictional or artistic work. ${ }^{224}$ In explaining this factor the United States Court of Appeals for the Ninth Circuit has said,

216. See May Ann Akers, Jackson Browne Defeats John McCain, The Washington Post (July 21, 2009, 3:06 PM, updated July 22, 2009, 9:35 AM), http://voices.washingtonpost.com/ sleuth/2009/07/john_mccain_really_running_on.html.

217. No. 7:96-CV-210-BR, 1998 U.S. Dist. LEXIS 7813 (E.D.N.C. Mar. 25, 1998).

218. See id. at *2, *16-18.

219. See id. at*17.

220. See id. at $* 3$.

221. See id. at *2-3.

222. See id. at *11-14.

223. See, e.g., Dr. Seuss Enters., L.P. v. Penguin Books USA, Inc., 109 F.3d 1394, 1402 (9th Cir. 1997) ("[T]his factor typically has not been terribly significant in the overall fair use balancing ....”).

224. See, e.g., Elvis Presley Enters. v. Passport Video, 349 F.3d 622, 629 (9th Cir. 2003). 
[W]orks such as original songs, motion pictures, and photographs taken for aesthetic purposes, are creative in nature and thus fit squarely within the core of copyright protection.... But works such as news broadcasts and news video footage are more factual in nature and thus are more conducive to fair use. ${ }^{225}$

Therefore, where the work in question is fact-based, this factor is likely to favor the party asserting the fair use defense.

While the work at issue here is copyrightable, ${ }^{226}$ the breadth of copyright protection for news is necessarily limited by the uncopyrightable nature of the facts reported. ${ }^{227}$ Therefore, the copyrighted content in question here is likely not at the heart of copyright protection. This factor will likely weigh in favor of the Romney campaign.

\section{The Amount and Substantiality Taken}

To decide whether this factor weighs in favor of the copyright owner or the alleged infringer, courts undertake both a qualitative and a quantitative analysis. ${ }^{228}$ They consider both the proportion of the work taken relative to the totality of the work and whether the alleged infringer took what constitutes the heart of the work, such that the infringed content acts as a market substitute for the copyrighted work. ${ }^{229}$ In that sense, the third and fourth factors inform each other. ${ }^{230}$ While there have been cases where the complete reproduction of a work constituted fair use, ${ }^{231}$ there is no definitive quantitative amount of content that will not potentially result in

225. Id. (internal citations omitted) (citing Sony Corp. v. Universal City Studios, Inc., 464 U.S. 417, 455 n.40 (1984); Kelly v. Arriba Soft Corp., 336 F.3d 811, 820 (9th Cir. 2002); L.A. News Serv. v. KCAL-TV Channel 9, 108 F.3d 1119, 1122 (9th Cir. 1997)).

226. See supra notes 88-93 and accompanying text.

227. See discussion supra Part IV.A; see also Nat'l Rifle Ass'n of Am. v. Handgun Control Fed'n of Ohio, 15 F.3d 559, 562 (6th Cir. 1994) ("The list in the NRA newsletter is almost entirely factual, and " $[\mathrm{t}]$ he law generally recognizes a greater need to disseminate factual works than works of fiction or fantasy." (quoting Harper \& Row, Publishers, Inc. v. Nation Enters., 471 U.S. 539,563 (1985))).

228. See Harper \& Row, Publishers, Inc., 471 U.S. at 564-66.

229. See id.

230. See Cambridge Univ. Press v. Becker, 863 F. Supp. 2d 1190, 1236 (N.D. Ga. 2012) ("I]f a professor used an excerpt representing $10 \%$ of the copyrighted work, and this was repeated by others many times, would it cause substantial damage to the potential market for the copyrighted work? The answer is no, because the $10 \%$ excerpt would not substitute for the original, no matter how many copies were made. In short, Defendants' use of small excerpts did not affect Plaintiffs' actual or potential sales of books.").

231. See, e.g., Bill Graham Archives v. Dorling Kindersley Ltd., 448 F.3d 605, 615 (2d Cir. 2006) (finding that use of concert posters in their entirety constituted fair use); Núñez v. Caribbean Int'l News Corp., 235 F.3d 18, 25 (1st Cir. 2000) (finding fair use where a newspaper reproduced photographs in their entirety). Note that both of these cases involved the use of photographs, which are difficult to reference without reproducing the entirety. 
infringement liability. ${ }^{232}$ Notably, fair use cases rarely turn upon the quantitative measure of the allegedly infringed content. ${ }^{233}$

Here, the Romney campaign could argue that it only used thirty seconds of a much longer broadcast. ${ }^{234}$ Of course, as noted in the above infringement analysis, there is no bright line rule as to what portion of a work may be used without infringing. To properly consider the qualitative aspect of this element, we must know more about the underlying broadcast. For example, if the snippet used by the campaign was the night's lead story, the portion used could arguably constitute the heart of the broadcast. A court arriving at such a conclusion is likely to hold that this factor favors NBC. While it is hard to say whether this factor would favor Romney or NBC, it is pretty clear that the factual record would have to be developed on this point. The same is true of the fourth factor.

\section{The Effect on the Market for the Work}

In evaluating this factor, courts consider not only the direct effect of the alleged infringer's conduct, but also whether similar conduct by others left unchecked would harm the market for the work. $^{235}$ A court might inquire as to whether there is a market to license the content, particularly when it represents only a small portion of the overall work. ${ }^{236}$ At bottom, if there is a market to license the content, courts tend to find that unauthorized uses harm that market. ${ }^{237}$

Any court hearing a dispute between Romney and NBC and considering a fair use defense will be interested in whether NBC licenses snippets such as the one in question here. If it does-and particularly if it does regularly and at a reasonable rate-the court is likely to find that uses like Romney's, if unchecked, will harm the market for those licenses.

\section{Fair Use: Conclusion}

While it is difficult to predict precisely what a court considering the fictional case of $N B C v$. Romney would decide as to the fair use question, there are some issues that can be resolved definitively and others that ought to give us pause. First, because fair use is

\footnotetext{
232. See supra notes 168-170 and accompanying text.

233. But see Cambridge Univ. Press, 863 F. Supp. 2d at 1236-37.

234. See supra note 169 and accompanying text.

235. See Campbell v. Acuff-Rose Music, Inc., 510 U.S. 569, 590 (1994).

236. See, e.g., Cambridge Univ. Press, 863 F. Supp. 2d at 1236-37.

237. See id.
} 
determined on a case-by-case basis and because the facts presented by a dispute between Romney and NBC do not necessitate a finding one way or the other, it is clear that a defendant pursuing such litigation undertakes a significant risk. This is particularly true in light of the potential for the award of statutory damages and attorney's fees. ${ }^{238}$ In addition, it is clear that deciding whether the campaign's conduct constitutes fair use requires some development of the factual record. This means that a court is unlikely to resolve this dispute until at least the summary judgment stage. Again, a defendant undertaking such litigation would have to consider the expense associated with litigating a copyright infringement suit through summary judgment, irrespective of the merits. Others have considered the chilling effect associated with the nature of the fair use determination. ${ }^{239}$ The analysis undertaken here demonstrates that effect.

The idea-expression dichotomy is unlikely to assist our fictional defendant; technical infringement is clear, and a finding of fair use is far from a foregone conclusion. On the other hand, First Amendment jurisprudence cautions that political speech requires the greatest protection, and the Copyright Act, as applied in this context, is arguably unconstitutionally vague. ${ }^{240}$ Approaching this question from the perspective of the Copyright Act would allow content owners to do what candidates themselves could not do without implicating the First Amendment; that is, suppress speech that is relevant to a candidate's qualifications for office. This divergence in potential outcomes depends solely upon whether one approaches the question from the perspective of the Copyright Act or the First Amendment. This demonstrates that the internal safeguards, as ordinarily utilized, do not fully protect the free speech interests at stake when copyright holders allege infringement in the context of a political campaign. What follows is an attempt to imbue fair use with the ability to protect free speech in this context. Doing so will require courts to presume fair use when the alleged infringement occurs in the context of a political campaign.

\section{AN ATTEMPT AT HARMONIZATION: REALIZING THE FIRST AMENDMENT POTENTIAL OF TRANSFORMATIVENESS}

In order for the fair use doctrine to protect the free speech interests at stake in a case like the fictional dispute between NBC and

238. See supra notes 220-222 and accompanying text.

239. See, e.g., Netanel, Locating Copyright Within the First Amendment Skein, supra note 34 , at $20-23$.

240. See discussion supra Part II. 
Romney, both procedural and substantive problems must be addressed. On the procedural side, the hesitation of courts to summarily adjudicate the issue of fair use presents a significant hurdle. ${ }^{241}$ It is untenable for a political campaign to litigate a copyright infringement suit in the absence of some reasonable expectation that the matter can be resolved with little fact-finding. A rebuttable presumption of fair use in this context would address this issue, recognizing that lengthy adjudications around issues of protected political speech during the heat of a campaign are anathema to the protection provided by the First Amendment. ${ }^{242}$

On the substantive side, the Supreme Court has already provided a rhetorical approach that could prove useful in this context: tranformativeness. In Campbell v. Acuff-Rose the Court developed the concept of tranformativeness to explain parody as fair use. ${ }^{243}$ As noted above, lower courts employ this analysis in cases that have nothing to do with parody. ${ }^{244}$ Utilizing that concept to evaluate fair use in political campaigns makes even more sense because transformative use as articulated in Campbell is protective of First Amendment interests. ${ }^{245}$ Specifically, courts treat parodies as potentially important social commentary. ${ }^{246}$ Political speech-speech undertaken by a candidate for political office in furtherance of his candidacy-deserves at least as much breathing room as parody. Therefore, the suggestion here is that courts considering allegations of copyright infringement in the context of political campaigns recognize the First Amendment interests at stake by expanding the notion of tranformativeness to encompass such uses.

\section{CONCLUSION}

This Article questions the decisions holding that the fair use defense and idea-expression dichotomy, as currently implemented, are sufficient to address the First Amendment issues that can arise in the context of copyright infringement suits. It asserts that there are instances, such as when the alleged infringement occurs in the context

241. See discussion supra Part III.A.

242. See supra notes 28-54 and accompanying text.

243. See Campbell v. Acuff-Rose Music, Inc., 510 U.S. 569, 579-82 (1994).

244. See supra notes 202-207 and accompanying text.

245. See, e.g., Dr. Seuss Enters., L.P. v. Penguin Books USA, Inc., 109 F.3d 1394, 1400 (9th Cir. Cal. 1997) ("[T]he inquiry is whether . . . and to what extent the new work is 'transformative,' i.e., altering [the copyrighted work] with new expression, meaning or message. Parody is regarded as a form of social and literary criticism, having a socially significant value as free speech under the First Amendment."); see generally Mel Marquis, Fair Use of the First Amendment: Parody and Its Protections, 8 SETON HALL Const. L.J. 123 (1997).

246. See id. 
of a political campaign, in which the First Amendment is squarely implicated and the internal safeguards are insufficient. In order to demonstrate this, this Article has undertaken a thought experiment approaching NBC's efforts to stop the Romney campaign from using a portion of an old television news broadcast in an advertisement from the perspective of the First Amendment and, in the alternative, from the perspective of recent copyright jurisprudence. Undertaking these analyses side-by-side shows that there are circumstances in which the internal safeguards, as currently deployed, are plainly inadequate. In such circumstances, courts ought to either explicitly consider the First Amendment as a defense or fortify the fair use analysis by reference to First Amendment principles. 